\title{
Erratum to: Selective Interaction of Amyloid Precursor Protein with Different Isoforms of Neural Cell Adhesion Molecule
}

\author{
Ke-ping Chen $\cdot$ Fei Dou
}

Published online: 20 January 2012

(C) Springer Science+Business Media, LLC 2012

Erratum to: J Mol Neurosci (2012) 46: 203-209

DOI 10.1007/s12031-011-9578-3

The original version of this article unfortunately contained a mistake. The correct address of corresponding author appears below.

The authors apologize to readers for this mistake.

The online version of the original article can be found at http://dx.doi. org/10.1007/s12031-011-9578-3.

K.-p. Chen · F. Dou ( $\varangle)$

Key Laboratory of Developmental Genes and Human Disease,

Ministry of Education, Institute of Life Science,

Southeast University,

Nanjing 210009, China

e-mail: douf@bnu.edu.cn

e-mail: feidou@yahoo.com

F. Dou

Key Laboratory of Cell Proliferation and Regulation Biology,

Ministry of Education, College of Life Science,

Beijing Normal University,

Beijing 100875, China 